\title{
Study of Extraction of Rare Earth Elements from Hard Coal Fly Ash
}

\section{Ingrid ZNAMENÁČKOVÁ' ${ }^{1)}$, Silvia DOLINSKÁ ${ }^{1)}$, Slavomír HREDZÁK ${ }^{1)}$, Vladimír ČABLÍK ${ }^{2)}$, Michal LOVÁS ${ }^{1)}$, Dana GEŠPEROVÁ ${ }^{1)}$}

\footnotetext{
1) VŠB - Technical University of Ostrava, Faculty of Mining and Geology, Institute of Clean Technologies for Extraction and Utilization of Energy Resources, 17. listopadu 15, 70800 Ostrava-Poruba, Czech Republic; email: znamenackova@saske.sk, sdolinska@saske.sk, hredzak@saske.sk, lovasm@saske.sk

${ }^{2)}$ Institute of Geotechnics of SAS, Watsonova 45, 04001 Košice, Slovak Republic
}

http://doi.org/10.29227/IM-2020-01-71

Submission date: 29-12-2019 | Review date: 03-03-2020

\section{Abstract}

Rare earth elements (REEs) extraction from wastes and/or by-products is alternative possibility of their winning. The occurrence of REEs, namely $50.1 \mathrm{ppm}$ of La, $100.1 \mathrm{ppm}$ of Ce and $44.3 \mathrm{ppm}$ of $\mathrm{Nd}$ was confirmed in solid fly ash samples from the coal fired heating plant (TEKO, Inc. Košice, eastern Slovakia). The submitted contribution presents laboratory results of REEs leaching from coal fly ash using $3 \mathrm{M} \mathrm{HCl}, \mathrm{HNO}_{3}, \mathrm{H}_{2} \mathrm{SO}_{4}$ and $\mathrm{H}_{3} \mathrm{PO}_{4}$ at $80^{\circ} \mathrm{C}$ during $120 \mathrm{~min}$.

It was found, that recoveries $65.5 \%$ of $\mathrm{La}, 64.4 \% \mathrm{Ce}$ and $64.3 \%$ of $\mathrm{Nd}$ into liquor may be attained after grain size reduction to below $5 \mu m$.

Keywords: coal fly ash, REEs extraction, inorganic acids

\section{Introduction}

Recently, REEs consumption continually increases due to their extensive application in various areas.

The content and distribution of lanthanides in rocks and coal is confirmed by the presence of REE-bearing uncommon minerals, such as monazite (Ce,La,Nd,Th) $\mathrm{PO}_{4}$, allanite $(\mathrm{Ce}, \mathrm{Ca}, \mathrm{Y})_{2}\left(\mathrm{Al}_{2} \mathrm{Fe}^{3+}\right)_{3}\left(\mathrm{SiO}_{4}\right)_{3}(\mathrm{OH})$, zircon $(\mathrm{Zr}, \mathrm{REE}) \mathrm{SiO}_{4}$, xenotime $\mathrm{YPO}_{4}$ (Kolker et al., 2017; Finkelman, 1981), rhabdophane (Ce,La,Y) $\mathrm{PO}_{4} . \mathrm{H}_{2} \mathrm{O}$ (Dai et al., 2014), florencite $\mathrm{CeAl}_{3}\left(\mathrm{PO}_{4}\right)_{2}(\mathrm{OH})_{6}$ and Ce-Nd-bearing (fluoro)carbonates, e.g. bästnasite (Ce,La,Y) $\mathrm{CO}_{3} \mathrm{~F}$ (Dai et al., 2016; Dai et al., 2017; Zhao et al., 2017). Besides electronic scrap, the wastes from mining and metallurgical industry and also coal combustion (by)products (CCPs), e.g. fly ash can consider to be a potential source of REEs. CCPs landfills often negatively influence the surroundings by their elutriation and in such way contaminate surface and ground waters. On the other hand performed scientific studies confirmed an interesting content of REEs in CCP. Moreover, within the frame of European Union REEs were recognized as critical raw materials by European Commission. All above mentioned facts caused the intensive research on REEs winning from coal fly ash.

Generally, the extraction of REEs from mineral resources is energy intensive and ecologically undesirable process. Moreover, from technological viewpoint, this process is also complicated and it includes various physical separation methods to obtain REE-bearing mineral concentrates and hydrometallurgical techniques for processing the concentrates, i.e. metals extraction from minerals by using suitable leaching agents.

Lin et al. (2017) dealt with the enrichment of REEs from coal, coal by-products and shales.

The samples of fly ash contained 312-623 ppm of REE or 378-754 REY, respectively. An enrichment of REEs was attained in non-magnetic product using magnetic separation.
As to gravity concentration, it is interesting that the highest REE content was not found in the heaviest fraction, probably due to insufficiently liberated REE-bearing minerals from others ones.

Blisset et al. (2014) evaluated the REEs content in six coal fly ashes from the United Kingdom (UK) and Poland. Apart from other things they presented REO content of four samples obtained from semi-anthracitic coal combustion at various places of processing scheme (flotation/rougher product to magnetic separation/non-magnetic product to hydrocycloning) at upgrading of fly ash. Thus, they assayed organic concentrate (REO $398 \mathrm{ppm}$ ) from rougher froth, magnetic concentrate (REO $270 \mathrm{ppm}$ ), fines from hydrocyclone overflow (REO $637 \mathrm{ppm}$ ) and coarse from hydrocyclone underflow (REO $560 \mathrm{ppm}$ ) from the feed of REO $505 \mathrm{ppm}$. After above mentioned it seems that REEs concentrate in in-organic non-magnetic matter.

Naturally, an application of hydrometallurgical techniques in REEs winning from coal fly ashes is also intensively investigated. The researchers pay attention to several technological parameters of leaching with the aim to attain maximal attainable REEs recovery. So, various leaching agents, $\mathrm{pH}$ value at leaching, influence of temperature, pressure, and stirring speed in consideration of coal fly ash composition are studied.

Cao et al. (2018) studied the coal fly ash containing 489 ppm REE. The leaching of fly ash in $3 \mathrm{M} \mathrm{HCl}$ at $60^{\circ} \mathrm{C}$, at 200 rpm during $120 \mathrm{~min}$. resulted in the following values of recovery: $71.9 \% \mathrm{La}, 66.0 \% \mathrm{Ce}$ and $61.9 \% \mathrm{Nd}$. Kashiwakura et al. (2013) studied the extraction of REE from coal fly ashes by leaching using $\mathrm{H}_{2} \mathrm{SO}_{4}$. King at al. (2018) dealt with acid and alkaline leaching of REEs from fly ashes from combustion of various coals. In dependence on origin of fly ash and $\mathrm{pH}$ of leaching they observed leachability of REEs. It was shown that acid leaching is suitable for one group of coal fly ashes, but 
Tab. 1. Chemical analysis of coal fly ash

Tab. 1. Analiza chemiczna popiołu węglowego

\begin{tabular}{|c|c|c|c|c|c|c|c|c|c|c|}
\hline $\begin{array}{c}\mathrm{SiO}_{2} \\
{[\%]}\end{array}$ & $\begin{array}{c}\mathrm{MgO} \\
{[\%]}\end{array}$ & $\begin{array}{c}\mathrm{CaO} \\
{[\%]}\end{array}$ & $\begin{array}{c}\mathrm{Fe}_{2} \mathrm{O}_{3} \\
{[\%]}\end{array}$ & $\begin{array}{c}\mathrm{Al}_{2} \mathrm{O}_{3} \\
{[\%]}\end{array}$ & $\begin{array}{c}\mathrm{MnO} \\
{[\%]}\end{array}$ & $\begin{array}{c}\mathrm{K}_{2} \mathrm{O} \\
{[\%]}\end{array}$ & $\begin{array}{c}\mathrm{La} \\
{[\mathrm{ppm}]}\end{array}$ & $\begin{array}{c}\mathrm{Ce} \\
{[\mathrm{ppm}]}\end{array}$ & $\begin{array}{c}\mathrm{Nd} \\
{[\mathrm{ppm}]}\end{array}$ & $\begin{array}{c}\mathrm{LOI} \\
{[\%]}\end{array}$ \\
\hline 44.6 & 1.68 & 4.22 & 6.22 & 21.20 & 0.085 & 1.07 & 55.6 & 100.1 & 49.5 & 15.22 \\
\hline
\end{tabular}

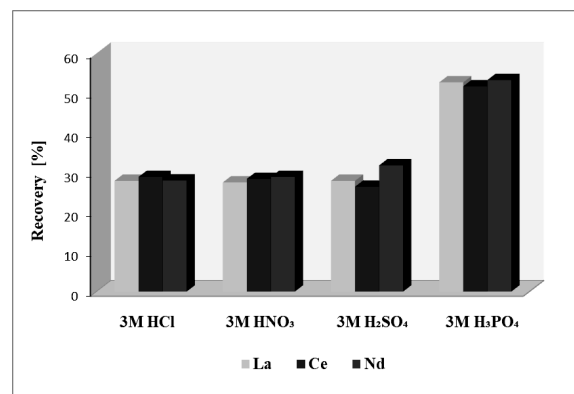

Fig. 1. Extraction La, Ce and Nd from coal fly ash (grain size $-100 \mu \mathrm{m}$ )

Rys. 1. Ekstrakcja La, Ce oraz Nd z popiołu węglowego (wielkość ziarna - $100 \mu \mathrm{m}$ )

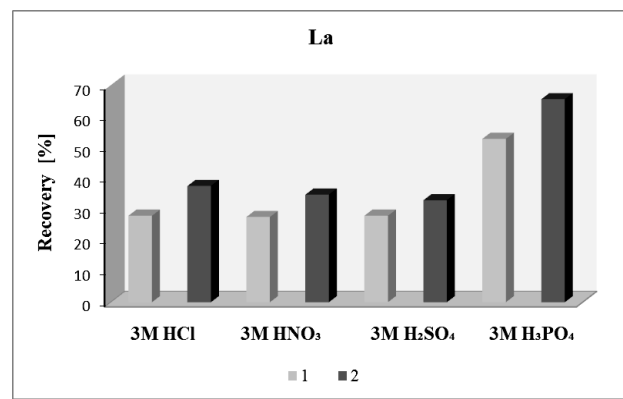

Fig. 2. Influence of grain size on extraction for $\mathrm{La}$ in $3 \mathrm{M} \mathrm{HCl}, 3 \mathrm{M} \mathrm{HNO}_{3}, 3 \mathrm{M} \mathrm{H}_{2} \mathrm{SO}_{4}$ and $3 \mathrm{M} \mathrm{H}_{3} \mathrm{PO}_{4} 1-$ grain size $-100 \mu \mathrm{m}$, $2-$ grain size $-5 \mu \mathrm{m}$ Rys. 2. Wpływ wymiaru ziarna na ekstrakcję La w $3 \mathrm{M} \mathrm{HCl}, 3 \mathrm{M} \mathrm{HNO}_{3}, 3 \mathrm{M} \mathrm{H}_{2} \mathrm{SO}_{4}$ i $3 \mathrm{M} \mathrm{H}_{3} \mathrm{PO}_{4} 1$ - wielkość ziarna - $100 \mu \mathrm{m}, 2$ - wielkość ziarna - $5 \mu$ m

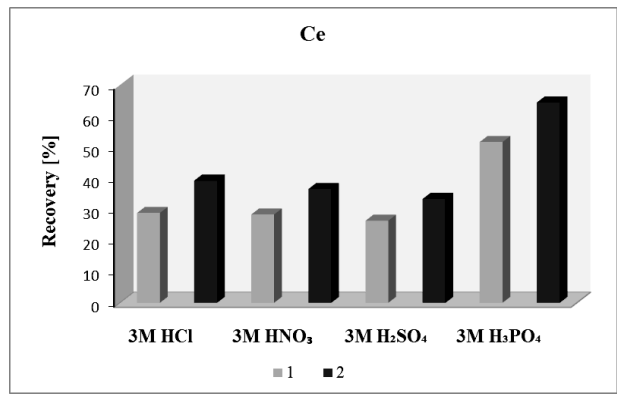

Fig. 3. Influence of grain size on extraction for Ce in $3 \mathrm{M} \mathrm{HCl}, 3 \mathrm{M} \mathrm{HNO}_{3}, 3 \mathrm{M} \mathrm{H}_{2} \mathrm{SO}_{4}$ and $3 \mathrm{M} \mathrm{H}_{3} \mathrm{PO}_{4} 1-$ grain size $-100 \mu \mathrm{m}, 2-$ grain size $-5 \mu \mathrm{m}$ Rys. 3. Wpływ wielkości ziarna na ekstrakcję Ce w $3 \mathrm{M} \mathrm{HCl}, 3 \mathrm{M} \mathrm{HNO}_{3}, 3 \mathrm{M} \mathrm{H}_{2} \mathrm{SO}_{4}$ i $3 \mathrm{M} \mathrm{H}_{3} \mathrm{PO}_{4} 1$ - wielkość ziarna - $100 \mu \mathrm{m}, 2$ - wielkość ziarna - $5 \mu \mathrm{m}$

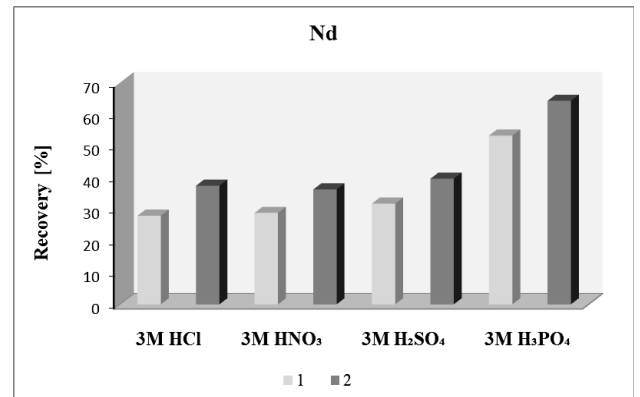

Fig. 4. Influence of grain size on extraction for $\mathrm{Nd}$ in $3 \mathrm{M} \mathrm{HCl}, 3 \mathrm{M} \mathrm{HNO}_{3}, 3 \mathrm{M} \mathrm{H}_{2} \mathrm{SO}_{4}$ and $3 \mathrm{M} \mathrm{H}_{3} \mathrm{PO}_{4} 1$ - grain size - $100 \mu \mathrm{m}, 2$ - grain size $-5 \mu \mathrm{m}$ Rys. 4. Wpływ wielkości ziarna na ekstrakcję $\mathrm{Nd}$ w $3 \mathrm{M} \mathrm{HCl}, 3 \mathrm{M} \mathrm{HNO}_{3}, 3 \mathrm{M} \mathrm{H}_{2} \mathrm{SO}_{4}$ i $3 \mathrm{M} \mathrm{H}_{3} \mathrm{PO}_{4} 1$ - wielkość ziarna - $100 \mu \mathrm{m}, 2$ - wielkość ziarna - $5 \mu \mathrm{m}$ 
on the other hand higher REEs recoveries into liquor were achieved using alkaline leaching in the case of the second sample group.

Wang et al. (2019) performed the study of bottom and fly ashes from the Luzhou power plant in Sichuan, (Southwest China) as a promising alternative resource for rare earth elements and yttrium (REE+Y or REY) recovery. The fly ash is characterized by an aluminosilicate composition with a low $\mathrm{CaO}$ content and it consists of $>70 \%$ amorphous glass and $<30 \%$ mineral phases such as mullite, quartz and iron oxides. Dissolution of the fly ash with $4 \%$ HF showed that $~ 90 \%$ of all the REY are associated with the amorphous glass. The optimal $\mathrm{NaOH}-\mathrm{HCl}$ sequential leaching resulted in $41.10 \%$ removal of active silica from the fly ash and $88.15 \%$ REY extraction.

\section{Materials and methods}

The sample of fly ash from the coal fired heating plant (TEKO, Inc. Košice, Slovakia) was subjected to leaching experiments on REEs extraction. The content of major components and lanthanides in fly ash is introduced in Table 1. The extraction was realized in glass banks in water bath at the temperature $80^{\circ} \mathrm{C}$ in $3 \mathrm{M}$ solutions of $\mathrm{HCl}, \mathrm{HNO}_{3}, \mathrm{H}_{2} \mathrm{SO}_{4}$ a $\mathrm{H}_{3} \mathrm{PO}_{4}$. The time of leaching was $120 \mathrm{~min}$ at the stirring speed $200 \mathrm{rpm}$. The ratio of leaching agent to solid phase was $100 \mathrm{ml}$ of solution to $1 \mathrm{~g}$ of solid sample. The content of lanthanides, namely La, Ce and Nd was determined by ICP-MS (Agilent 7700, USA). Silicon dioxide and Loss On Ignition (LOI) were assayed using gravimetric analysis (GA). The content of other metals was determined by AAS (Varian AA240FS, Australia).

The grain size reduction of fly ash sample to $-100 \mu \mathrm{m}$ was performed using a vibrating mill (VM-1, KSMH - Hranice, Czech Rep.). Further diminishing to grain size below $5 \mu \mathrm{m}$ realised by means of a planetary mill (Pulverisette 6, Fritsch, Germany) in grinding bowls at rotational speed of main disk $550 \mathrm{rpm}$. Tungsten carbide balls with diameter $10 \mathrm{~mm}$ were used as grinding media.

\section{Results and Discussion}

The results of laboratory experiments of lanthanides extraction from fly ash sample of grain size bellow $100 \mu \mathrm{m}$ in
$3 \mathrm{M} \mathrm{HCl}, \mathrm{HNO}_{3}, \mathrm{H}_{2} \mathrm{SO}_{4}$ and $\mathrm{H}_{3} \mathrm{PO}_{4}$ at $80^{\circ} \mathrm{C}$ during $120 \mathrm{~min}$ are shown in Fig. 1. Thus, leachability of observed lanthanides was confirmed by using all acid solutions. The highest recoveries $52.7 \%$ of $\mathrm{La}, 51.7 \%$ of $\mathrm{Ce}$ and $53.3 \%$ of Nd were attained using $3 \mathrm{M} \mathrm{H}_{3} \mathrm{PO}_{4}$.

Naturally, a grain size reduction of fly ash sample to $-5 \mu \mathrm{m}$ favourably resulted in the enhancement of REEs recovery into liquor by $5-12.8 \%$. The highest recoveries into liquor, namely $65.5 \%$ of $\mathrm{La}, 64.4 \%$ of $\mathrm{Ce}$ and $64.3 \%$ of $\mathrm{Nd}$ and the highest recovery increases by 12.8 of La, $12.7 \%$ of Ce and by $11 \%$ of $\mathrm{Nd}$ were again received by using $3 \mathrm{M} \mathrm{H}_{3} \mathrm{PO}_{4}$. The influence of grain size reduction on individual REE recovery is graphically illustrated in Figs. 2-4.

\section{Conclusion}

An attention to REEs recovery from hard coal fly ash was paid in submitted contribution. The samples of grain size below $100 \mu \mathrm{m}$ and $5 \mu \mathrm{m}$, respectively were subjected to acid leaching by using $3 \mathrm{M} \mathrm{HCl}, \mathrm{HNO}_{3}, \mathrm{H}_{2} \mathrm{SO}_{4}$ and $\mathrm{H}_{3} \mathrm{PO}_{4}$. Firstly, as to grain size below $100 \mu \mathrm{m}$ the recoveries $27.5-52.7 \%$ of $\mathrm{La}, 26.4-51.7 \%$ of $\mathrm{Ce}$ and $28-53.3 \%$ of $\mathrm{Nd}$ into liquor were obtained. Secondly, in the case of grain size below $5 \mu \mathrm{m}$ the recoveries $32.9-65.5 \%$ of $\mathrm{La}, 33.4-64.4 \% \mathrm{Ce}$ and $36.3-64.3 \%$ of $\mathrm{Nd}$ were won. The highest REEs recoveries were attained using $3 \mathrm{M} \mathrm{H}_{3} \mathrm{PO}_{4}$. Conversely, the application of $\mathrm{HNO}_{3}$ and $\mathrm{H}_{2} \mathrm{SO}_{4}$ as leaching agents seems to be inadequate. Finally, it can be stated, that grain size reduction resulted in higher REEs recovery into liquor by 5-12.8\%, mostly using $\mathrm{H}_{3} \mathrm{PO}_{4}$ (by $11-12.8 \%$ ).

\section{Acknowledgements}

This work was supported by the Slovak Grant Agency for Science VEGA grant No. 2/0055/17.

This publication is the result of the project implementation Research excellence centre on earth sources, extraction and treatment - 2nd phase supported by the Research \& Development Operational Programme funded by the ERDF (ITMS: 26220120038). 


\section{Literatura - References}

1. BLISSETT, R.S.; SMALLEY, N.; ROWSON, N.A. An investigation into six coal fly ashes from the United Kingdom and Poland to evaluate rare earth element content. In Fuel, 119, 2014, p. 236-239.

2. CAO, S.; ZHOU, C.; PAN, J.; LIU, C.; TANG, M.; JI, W.; HU, T.; ZHANG, N. Study on influence factors of leaching of rare earth elements from coal fly ash. In Energy Fuels 32, 2018, 7, p. 8000-8005.

3. DAI, S.; LUO, Y.; SEREDIN,V.V.; WARD, C.R.; HOWER, J.C.; ZHAO, L.; LIU, S.; TIAN, H.; ZOU, J. Revisiting the late Permian coal from the Huayingshan, Sichuan, southwestern China: Enrichment and occurrence modes of minerals and trace elements. In International Journal of Coal Geology 122, 2014, p. 110-128.

4. DAI, S.; LIU, J.; WARD, C.R.; HOWER, J.C.; FRENCH, D.; JIA, S.; HOOD, M.M.; GARRISON, T.M. Mineralogical and geochemical compositions of Late Permian coals and host rocks from the Guxu Coalfield, Sichuan Province, China, with emphasis on enrichment of rare metals. In International Journal of Coal Geology166, 2016, p. 71-95.

5. DAI, S.; XIE, P.; JIA, S.; WARD, C.R.; HOWER, J.C.; YAN, X.; FRENCH, D. Enrichment of U-Re-V-Cr-Se and rare earth elements in the Late Permian coals of the Moxinpo Coalfield, Chongqing, China: Genetic implications from geochemical and mineralogical data. In Ore Geology Reviews 80, 2017, p. 1-17.

6. FINKELMAN, R.B. Modes of occurrence of trace elements in coal U.S. Geological Survey Open File Report 81-99, 1981, $301 \mathrm{p}$.

7. KASHIWAKURA, S.; KUMAGAI, Y.; KUBO, H.; WAGATSUMA, K. Dissolution of rare earth elements from coal fly ash particles in a dilute H2SO4 solvent. In Open Journal of Physical Chemistry 3, No. 2, 2013, Article ID: 31621,7 p.

8. KING, J.F.; TAGGART, R.K.; SMITH, R.C.; HOWER, J.C.; HSU-KIM, H. Aqueous acid and alkaline extraction of rare earth elements from coal combustion ash. In International Journal of Coal Geology 195, 2018, p. 75-83.

9. KOLKER, A.; SCOTT, C.; HOWER, J.C.; VAZQUEZ, J.A.; LOPANO, C.L.; DAI, S. Distribution of rare earth elements in coal combustion fly ash, determined by SHRIMP-RG ion microprobe. In International Journal of Coal Geology 184, 2017, p. 1-10.

10. LIN, R.; HOWARD, B.H.; ROTH, E.A.; BANK, T.L.; GRANITE, E.J.; SOONG, Y. Enrichment of rare earth elements from coal and coal by-products by physical separations. In Fuel 200, 2017, p. 506-520.

11. WANG, Z.; DAI, S.; ZOU, J.; FRENCH, D.; GRAHAM, I.T. Rare earth elements and yttrium in coal ash from the Luzhou power plant in Sichuan, Southwest China: Concentration, characterization and optimized extraction. In International Journal of Coal Geology 203, 2019, p. 1-14.

12. ZHAO, L.; DAI. S.; GRAHAM, I.T.; LI, X.; LIU, H.; SONG, X.; HOWER, J.C.; ZHOU, Y. Cryptic sediment-hosted critical element mineralization from eastern Yunnan Province, southwestern China: Mineralogy, geochemistry, relationship to Emeishan alkaline magmatism and possible origin. In Ore Geology Reviews 80, 2017, p. 116-140.

\section{Badanie ekstrakcji pierwiastków ziem rzadkich z popiołu węgla kamiennego}

Ekstrakcja pierwiastków ziem rzadkich (REEs) z odpadów oraz/albo z produktów jest alternatywna możliwościa ich uzyskania. Obecność REEs, konkretnie 50,1 ppm La, 100,1 ppm Ce oraz 44,2 ppm Nd została potwierdzona w próbkach popiołu $z$ wegla $z$ elektrociepłowni (TEKO, Inc. Košice, wschodnia Słowacja). Prezentowany artykuł pokazuje wyniki laboratoryjne ługowania REEs $z$ popiotu weglowego za pomoca $3 \mathrm{M} \mathrm{HCl}, \mathrm{HNO}_{3}, \mathrm{H}_{2} \mathrm{SO}_{4}$ oraz $\mathrm{H}_{3} \mathrm{PO}_{4} w 80^{\circ} \mathrm{C} w$ czasie 120 minut. Odkryto, że odzysk 65,5\% La, 64,4\% Ce oraz 64,3\% Nd w formie ciekłej może być osiagnięte przy redukcji wymiaru ziaren do poniżej 5 um.

Słowa kluczowe: popiół węlowy, ekstrakcja REEs, kwasy nieorganiczne 